\title{
Malignant mesothelioma as a difficult interdisciplinary problem
}

\author{
Wojciech Rokicki, Marek Rokicki, Jacek Wojtacha, Mateusz K. Rydel \\ Department of Thoracic Surgery in Zabrze, Medical University of Silesia in Katowice, Poland
}

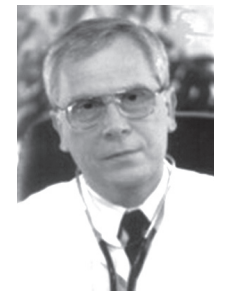

Kardiochirurgia i Torakochirurgia Polska 2017; 14 (4): 263-267

\begin{abstract}
The authors of the present report review the etiology and clinical symptoms of malignant pleural mesothelioma (MPM) as well as diagnostic techniques (both radiological and biomarkers) used for its detection. Subsequently, they present methods of multimodal treatment (surgery, chemotherapy, and radiotherapy) recommended by the International Mesothelioma Interest Group (IMIG). Finally, they discuss complications and long-term results associated with these methods of MPM treatment.
\end{abstract}

Key words: pleural mesothelioma, diagnosis and differentiation, IMIG consensus, adjuvant therapy, long-term results.

\section{Introduction}

Pleural mesothelioma is a rare malignant neoplasm characterized by an aggressive course and poor clinical prognosis. It originates from the cells of the parietal pleura, which is a thin elastic membrane lining the surface of the pleural cavity. The pleura emerges from the mesoderm and appears as early as during the $7^{\text {th }}$ week of embryonic development. It has 5 layers:

1) a single layer of mesothelial cells,

2) a thin layer of mesothelium-derived cells with a basal lamina,

3) a thin elastic superficial layer,

4) loose connective tissue containing adipose tissue, fibrocytes, fibroblasts, mast cells, other mononuclear cells, blood and lymphatic vessels, and nerves,

5) a deep fibroelastic layer adhering tightly to the underlying organs (lungs, muscles, etc.) [1].

The main causes of pleural mesothelioma are believed to include asbestos exposure. Asbestos is a hydrated silicate of various metals ( $\mathrm{Mg}, \mathrm{Na}, \mathrm{Ca}, \mathrm{Fe}$ ). The name asbestos is reserved for a certain group of mineral compounds with fiber length-to-diameter ratio of at least $100: 1$. Thin fibers (0.01 $\mu \mathrm{m}$ or less in diameter) pose the greatest danger as they permeate into the lower respiratory tract, digging into

\section{Streszczenie}

Autorzy przedstawiają etiologię, objawy kliniczne i metody diagnostyczne (obrazowe i biomarkery) służące do wykrywania złośliwego międzybłoniaka opłucnej (ZMO). Następnie omawiają multimodalne sposoby jego leczenia (chirurgiczne oraz chemioterapię i radioterapię) zalecane przez grupę International Mesothelioma Interest Group (IMIG). Przedstawiają powikłania i wyniki odległe leczenia ZMO po zastosowaniu powyższych metod.

Słowa kluczowe: międzybłoniak opłucnej, diagnostyka i różnicowanie, konsensus grupy IMIG, leczenie uzupełniające, wyniki odległe.

the tissue of the parietal pleura and the lungs; by chronically irritating the surrounding cells, they may cause the development of lung cancer or malignant pleural mesothelioma (MPM) [2].

The first clinical description of MPM comes from the year 1947 [3]. In 1960, Wagner et al. were the first to demonstrate that pleural mesothelioma occurs often among the inhabitants of the Republic of South Africa living in the vicinity of asbestos mines [4]. Reports arriving from various parts of the world confirmed these observations, demonstrating that asbestos inhalation is an etiological factor in MPM development [5]. Asbestos exposure is a significant medical problem: it has been demonstrated that in Scandinavia, USA, Japan, and Australia it causes approximately 20,000 deaths due to lung cancer and 10,000 deaths due to malignant pleural mesothelioma per year [6].

Malignant pleural mesothelioma is an insidious disease that is most often diagnosed by chance. The latency period between the initial exposure to asbestos and clinical symptoms may last 25-71 years [7]. Examinations fail to confirm asbestos exposure in approximately $20 \%$ of patients. Aggressive multispecialist treatment results in a survival time of 4-18 months from diagnosis. Mortality due to MPM

Address for correspondence: Mateusz K. Rydel MD, Department of Thoracic Surgery, Medical University of Silesia, Zabrze, Poland, phone: +48 506039 825, +48 506039 825, fax: +48 506039 825, e-mail: mateusz.rydel@wp.pl

Received: 15.01.2017, accepted: 27.05.2017. 
among men continues to slowly rise; among women, it remains at a constant level [8].

Until recently, infection with simian virus 40 (SV40) had been considered one of the primary causes of MPM as the virus was being found in human neoplastic cell lines. However, these observations of the role of SV40 continue to raise controversy because the virus was found in the tissues of only $5-6 \%$ of MPM patients. Hence the current view that SV40 does not play an important role in MPM development [9].

Pathomorphological diagnosis of the disease is challenging as it requires one to distinguish the malignant mesothelioma from benign epithelial outgrowths as well as other malignant tumors. Precise tissue diagnosis is necessary for prognosis because it determines not only the histological type of the lesion, but also the required treatment methods. The key indicator of mesothelioma malignancy is cellular invasion into the adipose tissue [10]. Tissue biopsy, the basic method of establishing diagnosis, must be correlated with imaging results and clinical symptoms. The tissue should be acquired using video-assisted thoracoscopic surgery (VATS) or open biopsy. Fine-needle biopsy is often insufficient for obtaining diagnosis or differentiating between MPM and pleural metastases of adenoma. At present, immunohistochemical staging distinguishes 4 types of mesothelioma: epithelioid, sarcomatoid, desmoplastic and mixed.

The epithelioid type, originating from cuboidal cells and found in $50-57 \%$ of patients, is the most common form of all malignant mesotheliomas and is associated with the best prognosis. The mixed type is diagnosed in approximately $24-34 \%$ of patients. The sarcomatoid type originates from spindle cells and is encountered in $16-19 \%$ of patients; it is associated with very poor prognosis with no 5 -year survivals. Desmoplastic tumors contain over $50 \%$ of dense, poorly cellular collagen and are associated with very poor prognosis: the median survival does not exceed 6 months [11].

The currently recommended method for differentiating benign and malignant mesotheliomas regardless of tissue infiltration is histoenzymatic investigation using GLUT-1 (glucose transporter 1) antibodies (positive results in 67\% of benign cases) and IMP-3 (insulin-like growth factor II messenger RNA-binding protein 3) with positive results in $73 \%$ of malignant cases [10]. Distinguishing MPM from pleural metastases of other neoplasms is a diagnostic challenge. In order to distinguish MPM from adenoma metastasis, staining with thyroid transcription factor 1 (TTF-1) or Napsin A is recommended. Squamous carcinoma is associated with positive expression of calretinin and CK5/6. Renal cancer gives positive PAX 8 or PAX 2 results, while CDX 2 is recommended to detect pleural metastases of gastrointestinal cancer. In turn, labeling estrogen receptors enables the detection of breast cancer metastases [3].

\section{Clinical symptoms and diagnostic methods}

Close cooperation between pulmonologists, radiologists, thoracic surgeons, anatomic pathologists, and oncologists is advisable in order to perform accurate diagnostics and establish a treatment plan for MPM patients. Initial diagnosis may be suggested by history of chest pain, dyspnea, and symptoms of life-threatening cardiac tamponade. Physical examination of MPM patient involves standard methods of assessing the chest and the respiratory system. Imaging examinations such as chest X-ray, computed tomography, and magnetic resonance enable precise evaluation of the condition's extent (infiltration of the chest wall, pericardium, and diaphragm). Positron emission tomography-computed tomography (PET-CT) is not recommended for MPM diagnostics [12]. The most common radiological symptoms of MPM include: thickening of the parietal pleura, presence of tumorous masses on the pleural surface, pleural effusion, as well as infiltration of the chest wall structures, pericardium, and diaphragm. The above examinations enable the determination of the stage of MPM. Other noteworthy methods of detecting malignant pleural mesothelioma include MPM biomarker labeling, which can provide support for both early diagnostics and follow-up examinations after treatment. The first discovered serum marker for mesothelioma was mesothelin (serum mesothelin-related protein - SMRP), belonging to the family of proteins associated with cellular membranes. Its expression is observed in mesothelial cells as well as in pancreatic and ovarian cancer. Rising concentrations of serum SMRP were demonstrated $1-5$ years before the onset of mesothelioma; it has been suggested that this marker can be used effectively in screening tests [13]. Another serum protein marker, with $100 \%$ sensitivity and $94 \%$ specificity, is fibulin-3. Differences in its concentrations in serum and pleural effusion have been demonstrated to depend on whether the patient suffers from mesothelioma or other malignant pleural neoplasms. Therefore, it is considered to be the most significant marker, and its appearance in blood serum is important for detecting preclinical stages of MPM [14].

Currently, the most established system for staging MPM is the scale published by the International Mesothelioma Interest Group (IMIG), which has been accepted and implemented by the Union for International Cancer Control (UICC) and the American Joint Committee on Cancer (AJCC). The scale is based on traditional TNM parameter assessment (Tabs. I-III). Based on these three parameters, the clinical stage of MPM can be determined (Tab. IV).

Most patients have lower stages (I or II) without lymph node metastases and with limited malignant infiltration; the initial treatment for these patients should be surgery. For the remaining patients (with stages III or IV), the treatment of choice should consist in palliative chemotherapy or solely symptomatic treatment with talc pleurodesis to limit pleural effusion [15].

\section{Treatment methods}

Due to the exceptionally aggressive character of MPM, the patients must be carefully selected in order to identify the group that can benefit from interdisciplinary treatment and the group that is to undergo minimal therapy burdened with high mortality. The combination of surgery, radiation 
Tab. I. Malignant pleural mesothelioma - T parameter $[15,36]$

\begin{tabular}{|c|c|}
\hline Parameter & Characteristics \\
\hline \multicolumn{2}{|c|}{ Primary tumor } \\
\hline TX & Primary tumor cannot be assessed \\
\hline TO & No evidence of primary tumor \\
\hline $\mathrm{T} 1$ & $\begin{array}{l}\text { One-sided parietal pleural involvement with or } \\
\text { without visceral pleural infiltration }\end{array}$ \\
\hline T1a & $\begin{array}{l}\text { One-sided parietal pleural involvement } \\
\text { (mediastinum, diaphragm) without visceral } \\
\text { pleural infiltration }\end{array}$ \\
\hline $\mathrm{T} 1 \mathrm{~b}$ & $\begin{array}{l}\text { One-sided parietal pleural involvement } \\
\text { (mediastinum, diaphragm) with focal infiltration } \\
\text { of the visceral pleura }\end{array}$ \\
\hline $\mathrm{T} 2$ & $\begin{array}{l}\text { One-sided parietal pleural involvement with at } \\
\text { least one of the following features: } \\
\text { - diffuse infiltration of the visceral pleura } \\
\text { including the fissure } \\
\text { - infiltration of lung parenchyma } \\
\text { - infiltration of diaphragm muscles }\end{array}$ \\
\hline T3 & $\begin{array}{l}\text { One-sided pleural involvement with at least one } \\
\text { of the following features: } \\
\text { - infiltration of the endothoracic fascia } \\
\text { - infiltration of the mediastinal adipose tissue } \\
\text { - solitary infiltration foci in the soft tissues of } \\
\text { the chest wall } \\
\text { - nontransmural infiltration of the pericardium }\end{array}$ \\
\hline T4 & $\begin{array}{l}\text { One-sided pleural involvement with at least one } \\
\text { of the following features: } \\
\text { diffuse or multifocal infilitration: } \\
\text { - of the soft tissues of the chest wall } \\
\text { - of the ribs } \\
\text { - extending through the diaphragm to the } \\
\text { peritoneum } \\
\text { - extending directly to the contralateral pleura } \\
\text { - of the spine } \\
\text { - extending through the whole thickness of the } \\
\text { pericardium } \\
\text { - of the myocardium } \\
\text { - of the brachial plexus } \\
\text { - involving the presence of neoplastic cells in } \\
\text { pericardial fluid }\end{array}$ \\
\hline
\end{tabular}

therapy, and chemotherapy may determine the treatment's success. It has been demonstrated that long-term survival in MPM is impossible if the cancer metastasizes to mediastinal lymph nodes.

\section{Surgical methods}

There are two groups of surgical procedures used for MPM stages I and II:

a) en bloc extrapleural pneumonectomy (excision of the lung, pleurae, pericardial sac, and diaphragm) - EPP,

b) pleurectomy/decortication with preservation of the pulmonary tissue $-P / D$.

It should be stressed at this point, that performing resection that is both macro- and microscopically radical (R0) is practically impossible due to the lack of surgical margins, unlike other solid tumors of pleura. It is important to realize that the planned operation of MPM is rather cytoreductive rather than radical [16].
Tab. II. Malignant pleural mesothelioma - N parameter

\begin{tabular}{ll} 
Parameter & \multicolumn{1}{c}{ Characteristics } \\
NX & Lymph node metastases cannot be assessed \\
\hline N0 & No lymph node metastases \\
\hline N1 & $\begin{array}{l}\text { Metastases in one or more intrapulmonary or hilar } \\
\text { lymph nodes }\end{array}$ \\
\hline N2 & $\begin{array}{l}\text { Metastases in subcarinal and/or ipsilateral } \\
\text { parasternal mediastinal lymph nodes }\end{array}$ \\
\hline N3 & $\begin{array}{l}\text { Metastases in contralateral mediastinal } \\
\text { and parasternal lymph nodes, ipsilateral or } \\
\text { contralateral supraclavicular and/or scalene } \\
\text { lymph nodes }\end{array}$ \\
\hline
\end{tabular}

Tab. III. Malignant pleural mesothelioma - M parameter

\begin{tabular}{ll} 
Parameter & Characteristics \\
M1 & Distant organ metastasis absent \\
\hline M2 & Distant organ metastasis present \\
\hline
\end{tabular}

Tab. IV. Clinical stages of MPM

\begin{tabular}{lccc} 
Stage & T parameter & N parameter & M parameter \\
I & $T_{1}$ & $N_{0}$ & $M_{0}$ \\
\hline IA & $T_{1 a}$ & $N_{0}$ & $M_{0}$ \\
\hline IB & $T_{1 b}$ & $N_{0}$ & $M_{0}$ \\
\hline II & $T_{2}$ & $N_{0}$ & $M_{0}$ \\
\hline III & $T_{1}, T_{2}$ & $N_{1}$ & $M_{0}$ \\
\cline { 2 - 4 } & $T_{1}, T_{2}$ & $N_{2}$ & $M_{0}$ \\
\cline { 2 - 4 } & $T_{3}$ & $N_{0}, N_{1}, N_{2}$ & $M_{0}$ \\
\hline IV & $T_{4}$ & Any N & $M_{0}$ \\
\cline { 2 - 4 } & Any T & $N_{3}$ & $M_{0}$ \\
\cline { 2 - 4 } & Any T & Any N & $M_{1}$ \\
\hline
\end{tabular}

The very aggressive surgical treatment in the form of extrapleural pneumonectomy can be performed in patients with: Karnofsky Performance Score > 70 pts, normal renal and liver function, thrombocytosis (> $400000 / \mathrm{mm}^{3}$ ), leukocytosis $\left(>8300 / \mathrm{mm}^{3}\right)$. Although less radical, pleurectomy with decortication has been associated with lower rates of postoperative mortality and circulatory/pulmonary impairments as well as with better tolerance of subsequent chemotherapy [16]. Treasure et al. believe that radical surgery in the form of extrapleural pneumonectomy combined with chemotherapy and radiation therapy (trimodal treatment) does not result in good outcomes [17]. This has been confirmed by hospital observations made by other authors, who report better survival rates after pleurectomy with decortication than after extrapleural pneumonectomy [16]. Additionally, Luckraz et al. reported that pleurectomy with decortication combined with adjuvant therapy offers better longterm outcomes than extrapleural pneumonectomy [18]. 
However, not all authors share this view when comparing extrapleural pneumonectomy and pleurectomy/decortication.

Complications of extrapleural pneumonectomy were observed in approximately $44.2 \%$ of patients, while postoperative mortality in highly specialized centers ranged from $2.2 \%$ to $7 \%$ [19]. Median survival after extrapleural pneumonectomy combined with multimodal therapy currently amounts to 10-35 months. To compare, the median survival after pleurectomy with decortication and multimodal therapy amounts to 8-20 months [20].

In 2011, the IMIG together with the International Association for the Study of Lung Cancer (IASLC) published a consensus report classifying pleurectomy in the treatment of MPM in three categories:

I. extended pleurectomy/decortication with removal of all tumor lesions and resection of the pericardium and/or diaphragm;

II. pleurectomy/decortication with removal large tumor lesions without pericardium or diaphragm resection;

III. partial pleurectomy (partial removal of the parietal and/ or visceral pleura) for diagnostic purposes with removal all macroscopic tumor lesions [21].

Lang-Lazdunski et al. report that approximately $12 \%$ of MPM patients treated with third method also undergo segmentectomy or lobectomy if it was needed [22]. Other centers treating patients with partial pleurectomy supplement the procedure with the excision of pulmonary tissue in order to remove macroscopic lesions and the tissue damaged during decortication [23]. In turn, Bolukbas et al. reported that macroscopically radical MPM resection can be performed in $62 \%$ of patients. Postoperative mortality was $4.8 \%$, and median survival was 21 months. The rate of 5-year survival among stage III MPM patients treated with trimodal therapy (surgery, chemotherapy, radiation therapy) was as high as $28 \%$ [24].

Three renowned European scientific societies (European Respiratory Society, European Society of Thoracic Surgeons, and British Thoracic Society) believe that the role of aggressive radical surgical treatment for MPM remains very ambiguous and that the treatment should only be performed in highly specialized centers providing MPM treatment. The median survival of patients treated in such centers using trimodal therapy is 1-2 years; approximately $19 \%$ of patients can live for $3-14$ years [25-27].

\section{Adjuvant therapy}

\section{Chemotherapy}

Although malignant pleural mesothelioma is highly resistant to chemotherapy, this method is recommended as adjuvant treatment. It consists primarily in the administration of cisplatin in combination with antifolates (Pemetrexed). Cisplatin is used as a first-line chemotherapeutic for MPM both in neoadjuvant and adjuvant therapy [28]. Other recommended combinations include cisplatin with sirolimus or gemcitabine [29]. Intraoperative lavage with a hyperthermic cytostatic solution (cisplatin combined with amifostine), used after extrapleural pneumonectomy, has been reported to have an important cytoprotective role [30, 31]. In turn, median survival among patients treated with chemotherapy alone amounts to 9.3-13.3 months [32].

\section{Radiation therapy}

Radiation therapy is most often used to supplement radical pleurectomy/decortication. Minatel et al. used the dose of 50 Gy per hemithorax. The authors reported the following results; median survival was 33 months, progression-free survival was 29 months, and 3-year survival was achieved by $49 \%$ of patients [33].

Currently, three treatment methods are recommended as adjuvant therapy for malignant pleural mesothelioma:

a) moderate-dose photon technique,

b) high-dose matched photon/electron technique,

c) high-dose intensity-modulated radiation therapy.

All three techniques are established methods of MPM treatment; the question which of the three is the most effective can be expected to be answered in the near future [34].

\section{Photodynamic therapy}

This method is used both after EPP and P/D as adjuvant treatment after these procedures. Its efficacy in treating MPM remains largely unknown [35].

\section{Disclosure}

Authors report no conflict of interest.

\section{References}

1. Mutsaers S. The mesothelial cell. Int J Biochem Cell Biol 2004; 36: 9-16.

2. Boulanger G, Andujar P, Pairon J, Billon-Galland M, Dion C, Dumartier P, Brochard P, Sobaszek A, Bartsch P, Paris C, Jaurand M. Quantification of short and long asbestos fibers to assess asbestos exposure: a review of fiber size toxicity. Environ Health 2014; 13: 59-64.

3. Yang $\mathrm{H}$, Testa J, Carbone M. Mesothelioma epidemiology, carcinogenesis and pathogenesis. Curr Treat Options Oncol 2008; 9: 147-157.

4. Wagner J, Sleggs C, Marchand P. Diffuse pleural mesothelioma and asbestos exposure in the North Western Cape Province. Br J Ind Med 1960; 17: 260-271.

5. Gennaro V, Ceppi M, Boffetta P, Fontana V, Perotta A. Pleural mesothelioma and asbestos exposure among Italian oil refinery workers. Scand J Work Environ Health 1994; 20: 213-215.

6. Tossavainen A. Global use of asbestos and incidence of mesothelioma. Int J Occup Environ Health 2004; 10: 22-26.

7. Bianchi C, Bianchi T, Tommasi M. Long latency periods in asbestos-related mesothelioma of the pleura. Eur J Oncol 2007; 12: 189-195.

8. Kukreja J, Jaklitsch M, Wiener D, Sugarbaker D, Burgers S, Baas P. Malignant pleural mesothelioma: overview of the North American and European experience. Thorac Surg Clin 2004; 14: 435-445.

9. Ziegler A, Seemayer C, Hinterberger M, Vogt P, Bigosch C, Gautschi O, Tornillo L, Betticher D, Moch H, Stahel R. Low prevalence of SV40 in Swiss mesothelioma patients after elimination of false-positive PCR results. Lung Cancer 2007; 57: 282-291.

10. Qudsia A, Aliya A, Husain M. Malignant mesothelioma diagnosis. Arch Pathol Lab Med 2015; 139: 978-980.

11. Corson J. Pathology of mesothelioma. Thorac Surg Clin 2004; 14: 447-460.

12. Wang Z, Reddy G, Gorway M, Higgins C, Jablons D, Ramaswamy M, Hawkins R, Webl W. Malignant pleural mesothelioma: evaluation with CT, MR imaging, and PET. Radiographics 2004; 24: 105-119.

13. Azim H Jr, Gaafar R, Abdel Salam I, El-Guindy S, Elattar I, Ashmawy A, Khorshid O. Soluble mesothelin-related protein in malignant pleural mesothelioma. J Egypt Nat Canc Inst 2008; 20: 224-239. 
14. Pass H, Levin S, Harbut M, Melamed J, Chiriboga L, Domington J, Huflejt M, Carbone M, Chia D, Goodglick L, Goodman G, Thornquist M, Lui G, de Perrot M, Tsao M, Goparaju C. Fibulin-3 as a blood and effusion biomarker for pleural mesothelioma. N Engl J Med 2012; 367: 1417-1427.

15. Scherpereel A, Astoul P, Bass P, Berghamans T, Clayson $H$, de Vuyst P, Di enemann H, Galateau-Salle F, Hennequin C, Hilleral G, Le Pèchoux C, Multi L, Pairo J, Sdtahel R, van Houtte P, van Meerbeeck J, Waller D, Weder W. Guidelines of the European Respiratory Society and the European Society of Thoracic Surgeons for the management of malignant pleural mesothelioma. Eur Respir J 2010; 35: 479-495.

16. Hasegawa S. Extrapleural pneumonectomy or pleurectomy/decortication for malignant pleural mesothelioma. Gen Thorac Cardiovasc Surg 2014; 62: 516-521.

17. Treasure T, Lang-Lazdunski L, Waller D, Bliss J, Tan C, Entwisle J, Snee M, O Brien K, Kilburn L, Spicer J, Landon D, Edwards J, Coombes G, Darlison L, Peto J. Extra-pleural pneumonectomy versus no extra-pleural pneumonectomy for patients with malignant pleural mesothelioma: clinical outcomes of the Mesothelioma and Radical Surgery (MARS) randomised feasibility study. Lancet Oncol 2011; 12: 763-772.

18. Luckraz H, Rahman M, Patel N, Szafranek A, Gibbs A, Butchart E. Three de cades of experience in the surgical multimodality management of pleural mesothelioma. Eur J Cardiothorac Surg 2010; 37: 552-556.

19. Rusch V, Baldini E, Bueno R. The role of surgical cytoreduction in the treat ment of malignant pleural mesothelioma: meeting Summary of the International Mesothelioma. Interest Group Congress, September 11-14 2012, Boston Mass. J Thorac Cardiovasc Surg 2013; 145: 909-910.

20. Flores M, Pass H, Seshan V, Dycoco J, Zakowski M, Carbone M, Bains M, Rusch V. Extrapleural pneumonectomy versus pleurectomy/decortication in the surgical management of malignant pleural mesothelioma: results in 663 patients. J Thorac Cardiovasc Surg 2008; 135: 620-623.

21. Rice D, Rusch V, Pass H, Asamura H, Nakano T, Edwards J, Giroux D, Hasegawa S, Kernstine K, Waller D, Rami-Porta R. Recommendations for uniform definitions of surgical techniques for malignant pleural mesothelioma. A consensus report of the International Staging Committee and the International Mesothelioma Interest Group. J Thorac Oncol 2011; 6: 1304-1312.

22. Lang-Lazdunski L, Bille A, Belcher E, Cane P, Landau D, Steele J, Taylor H, Spicer J. Pleurectomy/decortication, hyperthermic pleural lavage with povidone-iodine followed by adjuvant chemotherapy in patients with malignant pleural mesothelioma. J Thorac Oncol 2011; 6: 1746-1752.

23. Shimokawa M, Hasegawa S, Fukuoka K, Okada M, Yokoi K, Tanaka F, Ya manaka T, Daimon T, Nakano T. A feasibility study of induction pemetrexed plus cisplatin followed by pleurectomy/decortication aimed at macroscopic complete resection for malignant pleural mesothelioma. Jpn J Clin Oncol 2013; 43: 575-578
24. Bolukbas S, Eberlein M, Kudelin N, Demis M, Stallmann S, Fisseler-Eckhoff A Schirren J. Factors predicting poor survival after lung-sparing radical pleurectomy of IMIG stage III malignant pleural mesothelioma. Eur J Cardiothorac Surg 2013; 44: 119-123.

25. Scherpereel A, Astoul P, Baas P, Barghmans T, Clayson H, de Vuyst P, Dienemann H, Galateau-Salle F, Hennequin C, Hillerdal G, Le Pèchoux C, Mutti L, Pairon J, Stahel R, van Houtte P, van Meerbeeck J, Waller D. Guidelines of the European Respiratory Society and the European Society of Thoracic Surgeons for the management of malignant pleural mesothelioma. Eur Respir J 2010; 35: 479-499.

26. Sugarbaker D, Wolf A. Surgery for malignant pleural mesothelioma. Expert Rev Resp Med 2010; 4: 363-372.

27. Comitee BTS Soc. BTS statement on malignant mesothelioma in the UK 2007. Thorax 2007; 62 (suppl 2) 1-19.

28. Jackman D. Current options for systemic therapy in mesothelioma. Semin Thorac Cardiovasc Surg 2009; 21: 154-158.

29. Hartman M, Esposito J, Sugarbaker D. Combined treatment with cisplatin and sirolimus to enhance cell death in human mesothelioma. J Thorac Cardiovasc Surg 2010; 139: 1233-1240.

30. Richards W, Zellos I, Bueno R, Jaklitsch M, Janne P, Churieac L, Yeap B, Dekkers R, Hartigan P, Capalbno L, Sugarbaker D. Phase I and II study of pleurectomy/decortication and intraoperative intracavitary hyperthermic cisplatin lavage for mesothelioma. J Clin Oncol 2006; 24: 1561-1567.

31. Zellos L, Rickards WG, Capalbo L, Jaklits MT, Chirieac LR, Johnson BE, Bueno R, Sugarbaker DJ. A phase I study of extrapleural pneumonectomy and intracavitary intraoperative hyperthermic cisplatin with amifostine cytoprotection for malignant pleural mesothelioma. J Thorac Cardiovasc Surg 2009; 137: 453-458.

32. Merritt N, Blewett C, Miller J, Bennett W, Young J, Urschel J. Survival after conservative (palliative) management of pleural malignant mesothelioma. J Surg Oncol 2001; 78: 171-174.

33. Minatel E, Trovo M, Plesel J, Baresic T, Franchin G, Gobitti C, Rumeileh I, Drigo A, Fontana P, Pagan V, Trovo M. Radical pleurectomy/decortication followed by high dose of radiation therapy for malignant pleural mesothelioma. Final results with long-term follow up. Lung Cancer 2014; 83: 78-82.

34. Forster K, Smythe W, Starkschall G, Liao Z, Takanaka T, Kelly J, Vaporciyan A Ahamad D, Dong L, Salehpour M, Kamaki R, Stevens C. Intensity-modulated radiotherapy following extrapleural pneumonectomy for the treatment of malignant mesothelioma: clinical implementation. Int J Radiat Oncol Biol Phys 2003; 55: 606-616.

35. Paul S, Neragi-Miandoab S, Jaklitsch M. Preoperative assessment and therapeutic options for patients with malignant pleural mesothelioma. Thorac Surg Clin 2004; 14: 505-516.

36. Goldstraw P. Staging Manual in Thoracic Oncology. International Association For The Study Of Lung Cancer 2009. 